\title{
CAPITAL STRUCTURE POLICY DECISIONS IN NORDIC LISTED FIRMS
}

\author{
Tor Brunzell, Eva Liljeblom, Anders Löflund and Mika Vaihekoski*
}

June 3, 2013

Comments are welcome.

\begin{abstract}
In this paper we report the results from a survey among all publicly listed Nordic firms on their policy decisions concerning their capital structure. We find that more than 60 percent of the companies have rather or relatively flexible debt target, whereas a strict target or no target at all is approximately equally common. We also study the determinants for the strictness of the debt target, and find support for both firm characteristics as well as behavioral variables. We also study the link between capital structure policy and dividend policy, and find that dividend paying firms / firms with a definite dividend policy are more likely to have a stricter debt target. These results indicate that more research should be done on the joint setting of capital structure and dividend policies.
\end{abstract}

KEYWORDS: corporate finance, dividend policy, payout, debt target, capital structure, Nordic, Nasdaq OMX

JEL Classification: G31, M21, O16

In alphabetical order. Brunzell: Stockholm University, School of Business. E-mail: tb(at)fek.su.se. Liljeblom and Löflund: Hanken School of Economics, Department of Finance and Statistics. E-mail: eva.liljeblom(at)hanken.fi and anders.loflund(at)hanken.fi. Vaihekoski: University of Turku, School of Economics, Department of Accounting and Finance. E-mail: mika.vaihekoski(at)utu.fi. Latest version of the paper can be downloaded from http://users.utu.fi/moovai/. We are grateful for the comments from Hanna Silvola, Frederick Lindahl, Hannu Schadewitz, and others participants at the TSE seminar. Authors wish to thank Nils Liljendahl, Kirsi Noro, Magnus Blomkvist, and Anna Björn for research assistance. Financial support from NASDAQ OMX Nordic Foundation and Academy of Finland is gratefully acknowledged. 


\section{INTRODUCTION}

A dominating strand in research concerning corporate capital structures has been the study of the determinants of an implicit optimal capital structure, and the speed of the adjustment towards such a target (see, e.g., Frank and Goyal, 2009, and Faulkender et al., 2011). As such many of the empirical studies have been aimed at providing support for a particular theory of capital structure (such as the trade-off theory with taxation and bankruptcy costs, or the pecking-order theory). The results indicate that companies seem to aim towards some target, but are slow to change their capital structure for various reasons. Frank and Goyal (2009) identify six core factors which seem to get consistent signs and significance in explaining the variation in market-based leverage ratios. More recently, the existence of a target leverage ratio has been questioned in studies providing support for a path dependent capital structure, generated e.g. as the cumulative outcome of past attempts to time the equity market (e.g. Baker and Wurgler (2002), Welch (2004), and Hennessy and Whited (2005)). A few papers have also looked at behavioral determinants of leverage decisions (Barros and Silveira (2007), Frank and Goyal (2007)). However, there are only few papers (e.g., Graham and Harvey (2001)) that ask the company directly whether or not they have a target capital structure, and how strict it is.

In this study, we survey factors affecting capital structure decisions, and contribute by studying the determinants for the strictness of a capital structure target. We also contribute by analyzing how managerial factors may affect the firm's policy choices. We study both the role of the chairman's age on the strictness of the capital structure target, as well as the link between a defined dividend policy and the strictness of the capital structure target. Such a link may e.g. be seen as an example of "managerial fixed effects" if more control oriented managers tend to introduce more formal policies for both of them. Finally, we present results for the rationale behind the choice between short and long term debt, issuing seasoned equity and convertible debt. Our results are based on a survey conducted among the Chairmen (CMs) and the financial managers (CFOs) of the companies listed on the Nordic stock exchanges. The results are combined with financial data on the actual characteristics and performance of the firms, and behavioral data on the respondent (age). 
We find that more than 60 percent of the companies have a relatively flexible debt target, whereas a strict target or no target at all is approximately equally common among the rest of the companies. When studying the determinants of the strictness of the capital structure target, we find support for both firm characteristics such as profitability and solidity, but also for variables of a more behavioral nature (the chairman's age, and firm age). We also find support for the joint setting of capital structure and dividend policies in line with Faulkender, Milbourn and Thakor (2006). A stricter capital structure policy is more likely in dividend paying firms and well as in firms which according to the questionnaire responses have formulated a definite dividend policy.

In addition, we study the self-proclaimed importance of alternative explanations for the respondents' choice for the appropriate level of debt as well as the choice between long-term and short-term debt, convertible debt vs. straight debt and the decision to issue new equity. The results show that long-term debt is used over short-term debt mostly to minimize the risk of financial distress. Debt rating considerations play clearly a less important role. We document relatively high willingness to issue equity $(35.5 \%)$ or convertible debt $(20.8 \%)$. Firms carefully consider earnings per share dilution and the access to alternative sources of funds before undertaking a stock issue. Taxation or industry level debt-ratio benchmarking were not found to drive leverage choices. Interestingly, convertibles were seen as a source of cheaper debt (compared to straight debt) and as causing less earnings dilution than seasoned equity offerings.

The remainder of this paper proceeds as follows. The testable hypotheses are developed in the second section. The sample and survey method are discussed in section three. In section four we present the results together with discussion of their implications. The final section offers conclusions and some suggestions for further research.

\section{LITERATURE REVIEW AND HYPOTHESIS DEVELOPMENT}

Early research on optimal capital structure focused on the development of a model for optimal leverage. More recent research has studied the choice of the target, whether firms adjust towards this optimum, and what is the speed of adjustment. Results have shown that the 
costs of leverage and adjustment play a major role in setting the target leverage as well as the speed of adjustment towards this target (Faulkender et al., 2011). Stanton and Zechner (2009) suggest that the debt target is related e.g. to management compensation. Other studies have found that the leverage level is associated with firm's size and profitability, corporate tax rate, agency costs, expected inflation, and the tangibility of firm's assets (see, e.g., Rajan and Zingales (1995), Frank and Goyal (2009)). In addition, the timing of the market affects the decisions (see Baker and Wurgler (2002), Hennessy and Whited (2005)), even to the extent that one can question the existence of an actual target capital structure. On the other hand, Kayhan and Titman (2007) not only report evidence on links between the capital structure and external capital raised, but also find that over long horizons, such effects are partially reversed, and capital structures tend to move towards target debt ratios consistent with the tradeoff theories of capital structure.

Despite the focus on the question of the existence of a target debt ratio, relatively few studies have looked at the strictness of such a ratio. Graham and Harvey (2001) is one the exceptions. They report that $19 \%$ of their respondents (CFOs) declined following a target debt ratio, 37\% indicated having a flexible target, $34 \%$ a somewhat stricter target, while the remaining $10 \%$ committed to a strict target debt ratio. Large firms were more likely to have target debt ratios, while targets were stricter among investment-grade and regulated firms. In this paper, we contribute to the general question concerning the existence of a target capital structure by reporting survey results for Nordic listed firms concerning the strictness of their target leverage ratio.

We will also contribute by studying the determinants of a target capital structure. We are especially interested in two sub-questions concerning such determinants: the question of managerial effects, and the links to a defined dividend policy.

Our first sub-question relates to the interesting line of studies looking at managerial effects on leverage decisions. Frank and Goyal (2007) study the effect of top managers on corporate financial decisions. They find that differences among CEOs account for a great deal of variation in leverage among firms, as exemplified by a strong fixed effect associated with the CEO in a leverage regression. They also find that CEO incentives are associated with leverage adjustment speeds, and that when a CEO leaves, leverage typically drops. Also some CEO 
characteristics seem to be associated with leverage. Most notable is the negative relationship between CEO tenure and leverage. Although some such characteristics are significant, the authors note that they do not account for all that much of the variation in the data. The CFO also seems to be playing an important role. Also Barros and Silveira (2007) provide evidence of managerial fixed effects on corporate policies in Brazil, especially on the link between manager changes and variations in capital structures. On the other hand, Graham and Harvey (2001) found that targets were considered as important when the CEO had a short tenure or was young.

A lower leverage ratio in firms with an older manager would be in line with "behavioral consistency theory"1, which suggests that an individual behaves in a consistent manner across different comparable situations. Cronqvist, Makhija, and Yonker (2012) find support for the behavioral consistency in the form of a match between the personal leverage choices of CEOs, and their firms. If managers become more risk averse with age, as suggested e.g. by the results of Morin and Suarez (1983), and if they can influence the leverage decisions of the firm, a negative relationship between manager age and leverage level might be expected. Managerial risk aversion is also likely to play a role if costs associated with readjustments of optimal leverage ratio disproportionally affect managers personally as is often the case in large scale cost cutting programs involving layoffs and asset sales or liquidations. Risk averse managers are more likely to minimize disutility arising from painful down-sizing by controlling excessive leverage ex ante. As discussed further below, commitment to a strict debt ratio policy can reduce agency costs for the firm's debt holders. In gauging the determinants for debt policy strictness we separate out the effect of the level of leverage (solidity).

Our data includes questionnaire results concerning the firm's policy, answered by the chairman of the board. A positive association between strictness of debt policy and age of the board chairman is therefore consistent with a managerial risk aversion effect. Our first specific hypothesis of interest is thus:

H1: Companies with an older chairman of the board are more likely to have a stricter target capital structure.

1 See e.g. Allport (1937, 1966), Epstein (1979, 1980), and Funder and Colvin (1991). 
Our second sub-question deals with the combined existence of a dividend and a capital structure policy. To our knowledge, there are few studies looking at such links. Faulkender, Milbourn, and Thakor (2006) present an integrated theory for the capital structure and dividend policy choices, where they find both of these determined as implicit governance mechanisms. They also generate testable predictions from the theory and test them, obtaining strong support for the integrated approach i.e. that the two policies are jointly determined. However, between firms, different combinations of capital structure and dividend targets may be optimal.

We argue, in the spirit of Faulkender, Milbourn, and Thakor (2006), that shareholders want to minimize total agency costs through carefully co-ordinated dividend and debt policies. Commitment to an explicit (minimum) dividend payout policy helps reduce managerial agency costs by constraining the amount of free cash flow at the discretion of managers. Adopting a higher target debt ratio (above the level dictated by trade-off-theory) has a similar effect. However, a higher target debt ratio increases agency costs of debt due to increased expected bankruptcy costs. Creditors typically protect themselves by imposing solidity requirements e.g. through EBITDA-to-debt-ratio and dividend payout controls constraining the firms' use of dividend policy to reduce managerial agency costs. Hence, firms committed to a strict debt policy will face difficulties in complying to a minimum target dividend and we expect a negative relation between dividend payment and debt policy strictness. Would it not be optimal for firms to then choose a flexible debt policy? Not necessarily, because a strict target leverage policy signals lower agency costs of debt through the firm's commitment to cutting costs / selling assets upon income shocks in order to restore chosen leverage ratio. A joint optimization of dividend and debt policies is thus required in order to minimize total agency costs. We therefore expect a positive relation between existence of a firm dividend policy and the strictness of debt policy.

$\mathrm{H} 2$ : Companies with a defined dividend policy are more likely to have a stricter debtto-equity / capital structure target.

\section{DATA}

\subsection{The survey data}


This paper is based on the results of a questionnaire ${ }^{2}$, directed to all Chairpersons of the Board, CEOs as well as CFOs of firms in the Nordic countries (Denmark, Finland, Iceland, Norway, and Sweden). Separate questionnaires were sent to the three respondent groups. However, the questionnaires included some common questions especially on the short-term pressure felt. Our results utilize both the common questions, as well as some separate questions directed only to some respondent group. Appendix 1 of this paper lists the questions used in the survey, and to whom they were directed to.

The survey was conducted in two stages. In the first stage, the questionnaire was sent to the respondents in the Nordic firms listed on the exchanges operated by the OMX (now NASDAQ OMX), i.e. in Denmark, Finland, Iceland, and Sweden. This took place in early December 2007. In the second stage, in May 2008, the questionnaire was sent to the respondents in the firms listed at the Oslo Børs in Norway. The questionnaire was sent as a letter directed to a named respondent. The names and addresses of the respondents (i.e. the Chairmen of the Board, the CEOs, and the CFOs) were hand-collected into a database. Ultimately, the questionnaire was sent to 780 firms (2271 respondents, a number smaller than 3 times 780 since 69 firms were lacking specific CFOs) in total.

The respondents were promised total anonymity i.e. the responses and the respondent's identity is only available to the researchers and the results are reported only as a group. The overall response rate was $20.4 \%$, ranging from $10.3 \%$ for Norway to $29.3 \%$ for Sweden. ${ }^{3}$ The chairpersons were the most active respondents (158 responses), although the response rate was almost the same for all categories of respondents. Table 1 reports the response rates per country and category of respondents.

\subsection{Background data}

\footnotetext{
2 Much work was put on the optimal design of the questionnaire. Prior to the actual survey, the questionnaire was also tested on subsets of executives / board members and like both in Sweden as well as in Finland.

3 The response rate is typical to this kind of surveys. For example, Brav et al. (2005) had a response rate of 16 per cent in a study among selected public and private US companies, and Graham et al. (2001) had a response rate of 10.4 per cent in their recent study.
} 
The responses were matched with background information on firm financials and ownership concentration. The financial data is collected from three sources. Our primary source is the Amadeus database. Additional items have been collected from Datastream, when not available in Amadeus. Finally, annual reports downloaded from the web have provided an additional data source in cases where information has not been available in other databases. The financials are from the last reporting year completed prior to the questionnaire was sent out, i.e. they are mainly from the year-end 2006 for Denmark, Finland, Iceland, and Sweden, and from 2007 for Norway. Year-end exchange rates have been used to convert all financials to the same currency, euro, which already was the currency of Finland. Financial data was collected not only for responding firms, but also for the whole market, to facilitate relating our sample to the whole population of the survey. Table 2 reports descriptive statistics for responding firms and the whole population, separately for financial and non-financial firms. ${ }^{4}$ The value of solidity is not reported for the financials due to cross-sectional differences in how it is reported (that group of firms is very heterogeneous, including e.g. listed funds or investment companies, as well as insurance companies).

Table 2 shows that our firms are marginally larger than the population of firms to which the questionnaire was sent. This holds for the non-financial firms (285 in our sample) for all size related variables, but for the financials only in terms of Turnover. Our non-financial firms are also marginally less profitable (lower Return on Assets i.e. ROA), whereas our sample of financials (57 firms in our sample) are more profitable. The differences are however small and not statistically significant. We therefore conclude that our sample represents the total population quite well.

Ownership data for the firms has been collected primary from Amadeus, and secondary from annual reports from the web. The Amadeus data represents the ownership situation at the time point of the survey, while data from the annual reports is from the last reporting year prior to the survey. We collected data both on the ownership share (per cent of equity) of the largest

\footnotetext{
4 Many studies restrict their sample strictly to industrial firms, since financial variables such as solidity, and the value of total assets, are on a very different level for financials vs. non-financials. Since our prime focus is the responses to the questionnaire, which do not suffer from differences in measurement, we keep all respondents included. However, when relating responses to variables that may take very different values for financial vs. nonfinancial firms and because financial firms typically face explicit capital requirements, we keep the subsamples separated.
} 
shareholder, as well as the sum of the ownership share of the five largest owners (when available). The ownership is quite concentrated in the Nordic firms, with 42 firms (14\%) of firms having a majority owner, controlling more than 50\% of the shares, and 179 (60\%) having an owner controlling $20 \%$ or more of the equity.

We also tried to identify the owner type of the largest owner. The largest owner type in our sample are private investors (or families), $37.7 \%$ of the respondents coming from such firms. The other larger groups are firms owned by mutual funds or investment companies (16.4\%), other firms (12.1\%), or "activist" owners (classified as private equity firms, activist hedge funds or like) $(11.4 \%)$.

\section{RESULTS}

\subsection{The determinants of the strictness of the capital structure target}

We asked the CFOs whether the company has a target range for the debt (to equity) ratio. Four alternatives were given: 'no target range', 'flexible target range', 'somewhat tight target range', and 'strict target range'. The results are reported in Panel A of Table 3.

Out of the 158 responses from the CFOs, thirteen did not answer this question. Out of the 145 answers, 28 (19.3\%) companies indicated that they do not have a target debt ratio. Most of the companies $(80.7 \%)$ have a target range for their debt ratio, where 39 (26.9\%) have a flexible target ratio, $49(33.8 \%)$ have rather flexible target ratio, and $29(20.0 \%)$ have a strict target debt ratio. Analyzing the results country-by-country reveals no major differences between different nations, perhaps with the exception that Finnish and Icelandic companies being more likely to lean toward stricter target range in their capital structure. The results are rather similar to what Graham and Harvey (2001) found. In their sample of US firms, 19\% of the firms did not have a target debt ratio, whereas $81 \%$ do. However, they found that only $10 \%$ (vs. our $20.0 \%$ ) of the firms have a very strict target, and $37 \%$ had flexible and $34 \%$ rather flexible target (range). 
In order to test for the determinants for the strictness of the target capital structure, and to test our two specific hypothesis, we estimate an ordered probit model where the dependent variable, Strict_cap_struct, gets a value from one to four depending on the strictness of the target range for the debt levels. As explanatory variables in the base-case, we include financial control variables also familiar from prior studies of the determinants for leverage levels (Rajan and Zingales (1995), Baker and Wurgler (2002)).

First, we include profitability, size and solidity. Profitability is measured as the return on total assets, ROA. More profitable firms have higher degrees of freedom for the choice between how much to leave in the firm (how much to invest) and how much to pay out, and may also have higher agency costs due to higher free cash flows. They may therefore need to solve the agency problem by more explicit policies for capital structure and payout (including e.g. an upper limit for equity-to-assets). We expect a positive sign for ROA. Size in turn is measured by the logarithm of annual turnover, $\ln$ (turnover). We expect a negative sign for size, since larger firms have a better access to capital market and may therefore have a smaller need for strict capital structure targets. Solidity is measured as equity to total assets. We expect that the debt target is stricter in more leveraged firms, due to creditor control and thereby induced incentives to restrict agency costs of debt. This is in line with the results in Graham et al (2001), where the respondents (CFOs) told that the companies may issue equity to maintain a target debt-equity ratio especially if the firm is highly levered.

We also include Market-to-book, measured as the market value of equity over its book value, and Past_12m_sales_growth, measured as the change in sales between those reported in the last annual report and the report before that. In empirical leverage regressions, both of these have been found to correlate negatively with leverage (see e.g. Baker and Wurgler (2002)). However, for our model for the strictness of the capital structure target, we do not have explicit expectations for these. We also include the logarithm of the age of the firm, ln_firm_age. We expect that stricter capital structure targets have been more in need in times with less developed capital markets. By the inclusion of firm age we want to test whether these is a tradition in older firms for fixing stronger targets. ${ }^{5}$

\footnotetext{
A positive relation is also consistent with a survivorship bias in sampling - older firm category is likely to overrepresent strictly managed firms. Some less strictly managed firms disappear from the sample after episodes of financial distress. Further, simply due to the passage of time, (long-term) shareholders of older
} 
Finally, we include our main variables of interest, In_CM_age, the logarithm of the age of the chairman of the board at the time of the survey (i.e. the respondent to the survey questions on capital structure and dividend policy), and Div_policy_dummy, a survey variable taking the value of one if the chairman has indicated that the firm has a defined dividend policy. With the inclusion of Div_pay we test whether capital structure policies are more or less common in dividend paying firms. The tested model is an ordered probit model (estimated using maximum likelihood with robust standard errors) of the following type:

$$
\begin{aligned}
\text { Strict_cap_struct }_{i}= & \beta_{0}+\beta_{1}\left(F I R M_{-} C H A_{i}\right) \\
& +\beta_{2}\left(\text { ln_CM_age }_{i}\right)+\beta_{3}\left(\mathrm{DIV} \_\right. \text {POLICY } \\
& +\beta_{4}\left(\text { Sector_dummies }_{i}\right)+\beta_{5}\left(\text { Country_dummies }_{i}\right)+\varepsilon_{i},
\end{aligned}
$$

where FIRM_CHAR $R_{i}$ is a vector including ROA, In(turnover), Solidity, Market-to-book, Past_12m_sales_growth, and In_firm_age. DIV_POLICY $i$ is a vector including Div_policy_dummy, a dummy taking the value of one if the respondent has indicated that the firm has a defined dividend policy, and zero otherwise, and Div_pay, a dummy taking the value of one if the firm paid a dividend during any of the years around the questionnaire (2006 to 2008), and zero otherwise. Sector dummies for banking and manufacturing as well as country dummies for Denmark, Norway and Sweden are also included. ${ }^{6}$ The results are reported in Table 4.

Model I in Table 4 reports the results from a basic model with only the three main corporate control variables for which we have a clear expectation (ROA, $\ln$ (turnover), and Solidity). The behavioral variables of $I n \_f i r m \_a g e$ and $l n \_C M \_a g e$ are also included. We obtain expected signs for all of these, and all but size, are significant at least at the $10 \%$ level. Model II also includes the remaining firm characteristics, i.e. Market-to-book and Past_12m_sales_growth. These obtain positive signs but are not significant in this specification. Next, we also include

firms have experienced several financial distress episodes and have learnt about the relative benefits and costs of debt policy strictness and are therefore more likely to have adopted it than younger firms.

6 This leaves two countries with close to identical coefficient estimates (if included and some other country left out) without a dummy. There are only 4 observations for Iceland. The results are robust to the inclusion of a dummy for Iceland as well. 
Div_pay (in Model III), and Div_policy_dummy, the survey variable (in Model IV). ${ }^{7}$ We find that the dummy for a defined dividend policy obtains a positive sign as expected, and is highly significant. Robustness tests reveal that it is significant in all specifications where included. In Model IV, also ln(turnover) is significant at the $10 \%$ level.

We performed additional robustness tests of the models in Table 4 . When the model is estimated only for non-financial firms, the significance of some of the corporate characteristics decline, but both $I n \_C M \_a g e$ as well as Div_policy_dummy remain highly significant. However, also ROA and Solidity are significant also e.g. in Model I specification without financials. In the Graham et al (2002) study, the respondents (CFOs) told that the companies may issue equity to maintain a target debt-equity ratio especially if ownership is dispersed. In a specification equal to Model IV, we included a dummy taking the value of 1 if the five largest owners owned more than $20 \%$ of the equity, and zero otherwise. The variable is insignificant with a positive coefficient estimate, not supporting the result in Graham et al (2002).

In this section, we reported the results from our survey concerning the responses to the question on the strictness of the firms' capital structure target, and performed tests of the determinants of policy strictness. We find that a stricter target capital structure is more common in profitable, and in leveraged firms. A simple interpretation may be that these are cases where the specification of either a maximum level for equity-to-assets, or a minimum one, may be required from owners (due to agency costs associated with free cash flow), or creditors, respectively. We also find support for managerial effects: a stricter capital structure target is more common if the chairman is older. This finding is in line with managerial risk aversion affecting the choice of debt policy strictness.

We also find that a stricter policy is more common in older firms, a finding that perhaps may also be addressed to behavioral / traditional reasons. Finally, we find that a stricter capital structure policy goes hand in hand with a dividend policy. Both the dummy for a dividend paying firm, as well as the response variable from the questionnaire, confirming the existence of a definite dividend policy, obtain significance in explaining the strictness of the capital structure target. The fact, that dividend policy variables retain their significance to debt policy

7 The correlation between these two dividend variables is high, 0.49 , hence they are not included in the same model. 
strictness even in the presence of a leverage (level) control, supports the notion that dividend and debt policies need to be coordinated jointly.

\subsection{The level of the capital structure target}

We also asked both the CFOs and Chairmen to evaluate the importance of several alternative explanations to the selection of the appropriate level of debt for the company. A scale from one (not important) to five (highly important) was given for each explanation. Table 5 show the results, first for CM (Panel B) and then for CFOs (Panel C). The results show that both $\mathrm{CM}$ and CFOs consider the financial flexibility and operational financing as the most important factors in deciding the appropriate amount of debt for the company. The volatility of the earnings (cash flows) was third important aspect for both. On the other end, both respondent groups agreed that debt levels are not set to use it as way of avoiding the threat of being a target for a takeover nor for tax reasons.

Our results are quite consistent with Graham and Harvey (2001) who document that financial flexibility, credit rating, earnings/cash flow volatility and insufficient internal funds (in our case "operational financing") are the four most important determinants of debt policy.

\subsection{Short-term vs. long term debt}

We asked the CFOs what factors affect their company's choice between short and long-term debt. Five different potential reasons were given. Respondents were asked to evaluate each reason on a scale from 1 (not important) to 5 (very important). The results are provided in Table 5 .

The most important factor is clearly the use of long term debt to minimize risk of financial risk (mean answer 3.47). It is followed by the hope of matching the maturity of debt and assets (mean 3.21). Both explanations are clearly of strategic nature, whereas the two least important factors, use of short-term debt to wait long-term rates to decline (2.37) and wait with longterm issuance until rating has improved (1.80), are more of speculative nature. 


\subsection{Seasoned equity offerings}

We also asked the CFOs whether their company had seriously considered issuing common stock during the last two years. If yes, they were further asked to evaluate potential factors that typically affect company's decision to issue common stock. Ten different potential reasons were given and in case the respondents evaluated them on a scale from 1 (not important) to 5 (very important). The results are provided in Table 6.

Out of the 157 responses from the CFOs, thirteen did not answer this question. $54(35.5 \%)$ of the companies had considered issuing common stock whereas $98(64.5 \%)$ had not. This is almost similar to Graham and Harvey (2001) who found that $36 \%$ of their sample firms had seriously considered issuing equity. Earnings per share dilution and inability to obtain funds from other sources were found to be the most important contributing factors when considering the decision whether or not to issue common stock. Taxation and competitor's debt-to-equity rations were, on the other hand, found to be the least important contributing factors.

\subsection{Convertible debt}

Finally, we asked the CFOs whether their company had seriously considered issuing convertible debt during the last two years. If yes, they were further asked to evaluate potential factors that typically affect company's decision to issue common stock. Eight different potential reasons were given and in case the respondents evaluated them on a scale from 1 (not important) to 5 (very important). The results are provided in Table 7.

Out of the 154 responses from the CFOs, 32 (20.8\%) gave an affirmative answer and 122 (79.2\%) negative answer. Finding only one fifth of the companies to seriously consider convertible debt is somewhat surprising. On the other hand, the results are again almost similar to what Graham and Harvey (2001) found. In their sample $20 \%$ of the firms had seriously considered issuing convertible debt.

In Panel B, we can see that the most important factor contributing to the choice of convertible debt is the (conceived) notation that it is cheaper than debt. The second most important reason 
is that convertible debt avoids short-term equity dilution (against the alternative of SEO). Successful examples from others was not found important nor the aim to protect bondholders against managers and/or stockholders.

\section{CONCLUSIONS}

In this paper we analyze the results from a survey among all publicly listed Nordic firms on their policy decisions their capital structure. The results show that more than 60 percent of the companies have rather or relatively flexible debt target, whereas a strict target or no target at all is approximately equally common among the rest of the companies. When studying the determinants of capital structure strictness, we find support for firm characteristics as well as variables of a behavioral nature. More profitable, and more levered firms are more likely to have a stricter capital structure policy. The latter finding is similar to that in Graham et al (2002). These may be interpreted as cases when there is pressure for the specification of either a minimum or a maximum equity-to-assets level (from creditors, or owners due to agency problems of free cash flow). We also find that the age of the respondent (the chairman of the board) is significantly positively related to the strictness of the capital structure policy. This is in line with the "behavioral consistency theory" and the results of e.g. Cronqvist et al. (2012), suggesting a match between the choices of the firm and the manager, conditional on older managers being more risk averse (Morin and Suarez, 1983). We also find that a stricter debt target is more common in older firms. Finally, we find support for a link between the strictness of the capital structure target and the firms' dividend policy. Stricter debt targets are more common among dividend paying firms, and firms whose respondents indicate that the firm has a definite dividend policy. These results support the joint setting of capital structure and dividend policies (as presented in Faulkender et al., 2011), and suggest that more research should be targeted to the joint analysis of these two.

In our survey of Nordic listed firms, we also find that CFOs emphasize the use of long-term debt over short-term mostly to minimize the risk of financial distress. Debt rating considerations play clearly a less important role in the companies. Surprisingly many companies had considered seasoned equity offering $(35.5 \%)$ or issuing convertible debt $(20.8 \%)$. Earnings per share dilution and inability to obtain funds from other sources were found to be the most 
important contributing factors when considering the decision whether or not to issue common stock. Taxation and competitor's debt-to-equity rations were, on the other hand, found to be the least important contributing factors. On the other hand, the most important factor contributing to the choice of convertible debt is the (conceived) notation that it is cheaper than debt. The second most important reason is that convertible debt avoids short-term equity dilution (against the alternative of SEO). 


\section{REFERENCES}

Allport, G.W., 1966. Traits revisited. American Psychologist 21, 1-10.

Baker, M. and Wurgler, J., 2002. Market timing and capital structure. Journal of Finance 57, 1-30.

Barclay, M., Smith, C., and Watts, R., 1995. The Determinants of Corporate Leverage and Dividend Policies. Journal of Applied Corporate Finance 7(4), 4-19.

Berk, J., Stanton, R. and Zechner, J., 2010. Human capital, bankruptcy and capital structure. Journal of Finance 65, 891-926.

Brunzell, T., Liljeblom, E. and Vaihekoski, M., 2011. Determinants of capital budgeting methods and hurdle rates in Nordic firms. Accounting \& Finance 53, 85-110.

Cronqvist, H., Makhija, A.K. and Yonker, S.E., 2012. Behavioral consistency in corporate finance: CEO personal and corporate leverage. Journal of Financial Economics 103, $20-40$.

DeAngelo, H., DeAngelo, L. and Skinner, D.J., 2008. Corporate payout policy, in Foundations and Trends in Finance, Nos. 2-3, 95-287

Epstein, S., 1979. The stability of behavior: on predicting most of the people much of the time. Journal of Personality and Social Psychology 37, 1097-1126.

Fama, E. and French, K., 2002. Testing tradeoff and pecking order predictions about dividends and debt. The Review of Financial Studies 15, 1-33.

Faulkender, M., Flannery, M., Smith, J. and Haskins, K. W., 2011. Cash flows and leverage adjustment. Journal of Financial Economics, forthcoming.

Frank, M. and Goyal, V. K., 2009. Capital structure decisions: Which factors are reliably important? Financial Management 38, 1-37.

Funder, D.C. and Colvin, C.R., 1991. Explorations in behavioral consistency: properties of persons, situations, and behaviors. Journal of Personality and Social Psychology 60, 773-794.

Gaver, J. J. and Gaver, K. M., 1993. Additional evidence on the association between the investment opportunity set and corporate financing, dividend, and compensation policies. Journal of Accounting and Economics 16, 125-160.

Gomes, A., 2000. Going public without governance: managerial reputation effects. Journal of Finance 52, 615-646.

Graham, J. R. and Harvey, C. R., 2001. The theory and practice of corporate finance. Journal of Financial Economics 60, 187-243.

Hennessy, C.A. and Whited, T.M., 2005. Debt dynamics. Journal of Finance 60, 1129-1165.

Jensen, G. R., Solberg, D. P. and Zorm, T. S. 1992. Simultaneous Determination of Insider Ownership, Debt, and Dividend Policies. Journal of Quantitative Analysis 27(2), 247263.

Kayhan, A. and Titman, S., 2007. Firm's histories and their capital structures. Journal of Financial Economics 83, 1-32. 
La Porta, R., López de Silanes, F., Shleifer, A. and Vishny, R., 1998. "Law and Finance". Journal of Political Economy 106, 1113-1115.

Liljeblom, E. and Vaihekoski, M., 2009. Corporate Ownership and Managerial ShortTermism: Results from a Finnish Study of Management Perceptions. International Journal of Production Economics 117, 427-438.

Maury, B., 2006. Family ownership and firm performance: Empirical evidence from Western European corporations. Journal of Corporate Finance 12, 321-341.

Morin, R.A. and Suarez, A.F., 1983. Risk aversion revisited. Journal of Finance 38, 12011216.

Myers, C., 1984. The capital structure puzzle. Journal of Finance 39(3), 575-592.

Rajan, R.G. and Zingales, L., 1995. What do we know about capital structure? Some evidence from international data. Journal of Finance 50, 1421-1460.

Welch, I., 2004. Capital structure and stock returns. Journal of Political Economy 112, 106131. 
APPENDIX: The questions from the survey included in this study. Questions 1 and 2 were directed to the Chairmen, and the rest to the CFOs.

1. Does the Company have a defined dividend policy?

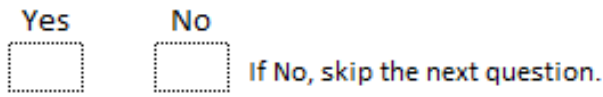

2. Which factors are important in the formulation of the Company's dividend policy:

not important - very important

A sustainable change in earnings

b. Stability and future earnings

c. The Company intends to pay a fraction of given earnings to shareholders for a long-term (given payout ratio)

d. The market price of the Company's stock is enhanced by dividend yield (given dividend yield)

e. Accumulate cash on hand

f. Financial leverage verses equity (target company structure)

g. Tax, i.e., Company shareholders pay dividend tax

h. Impact from the Company's current owner

i. Attract new investors

j. Method of satisfying minority owners

k. Maintain a capital structure that will allow the company to make good investments

I. Dividend policy of competitors or other companies within same sector

$\mathrm{m}$. Salary increases/reductions of Company employees

3. Does Your Company have a target range for Your debt ratio?

\begin{tabular}{|c|c|c|c|}
\hline 1 & 2 & 3 & 4 \\
\hline & & & \\
\hline & & & \\
\hline & & & \\
\hline & & & \\
\hline & & & \\
\hline & & & \\
\hline & & & \\
\hline & & & \\
\hline & & & \\
\hline & & & \\
\hline & & & \\
\hline & & & \\
\hline & & & \\
\hline
\end{tabular}

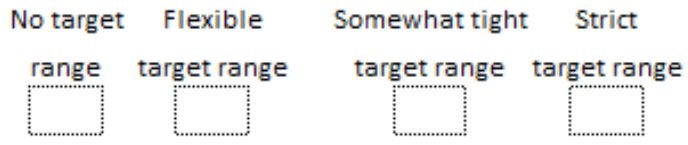

4. What factors affect how You choose the appropriate amount of debt for Your Company?

not important - very important

- Financial flexibility

- Our credit rating (as assigned by rating agencies)

- The tax advantage of interest deductibility

- The volatility of our earnings and cashflows

- The transactions costs and fees for issuing debt

- The potential costs of bankruptcy or near

bankruptcy financial distress

- The debt levels of other companies in our industry

- The personal tax cost that our investors face when

they receive interest income

- We try to have enough debt so that we are not an

attractive target

- To finance our operations

- Stock price valuation

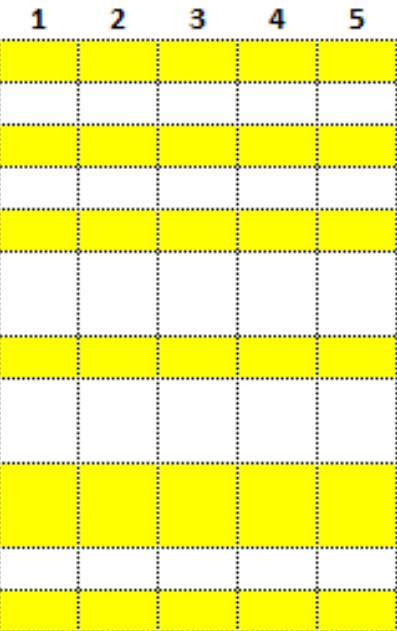


5. What factors affect Your Company's choice between short- and long-term debt?

- Matching the maturity of our debt with the life of
our assets
- Issuing long-term debt to minimize the risk of
having financial distress
- Issuing short term debt when we are waiting for
long term market interest rates to decline
- Expecting our rating to improve, so we borrow
short term until it does
- Borrowing long-term increases the risk of taking
on more risk project

6. Has Your Company seriously considered issuing common stock (in the last two years)?

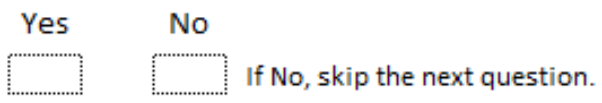

7. What factors affect Your Company's decisions about issuing common stock? not important - very important

- Earning per share dilution
- If our stock price has recently risen, the price at
which we can issue is "high"
- Maintaining a target debt-to-equity ratio
- Providing shares to employee stock option plan
- The amount by which our stock is undervalued or
overvalued by the market
- Diluting the holdings of certain shareholders
- Whether our recent profits have been sufficient to
fund our activities
- Using a similar debt/equity ratio as is used by
other companies in our industry
- The capital gains tax rates faced by our investors
(relative to tax rates on dividends)
- Inability to obtain funds using other sources

8. Has Your Company seriously considered issuing convertible debt (or issued debt in the last two years)?

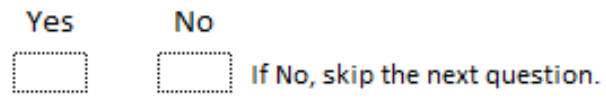

9. What factors affect Your Company's decision to issue convertible debt?

not important -- very important

- Ability to "call" or force conversion of convertible
debt if/when we need to
- Avoiding short-term equity dilution
- Our stock is currently undervalued
- Convertibles are an inexpensive way to issue
"delayed" common stock
- To attract investors unsure about the riskiness of
our Company
- Convertibles are less expensive than debt
- Other companies in our industry successfully use
convertibles
- Protecting bondholders against unfavourable
actions by managers or stockholders




\section{TABLE 1. Descriptive statistics}

Descriptive statistics are reported for the responses received from a survey directed to the Chairmen (CMs), Chief Executive Officers (CEOs), and Chief Financial Officers (CFOs) of all companies listed at the Nordic Stock Exchanges at the end of 2007 (except for Norway) and in May 2008 (Norway). A total of 780 companies were included and 2271 surveys sent.

\begin{tabular}{lrrrr}
\hline \hline & CM & CEO & CFO & Sum \\
\hline Panel A: Number of responses & & & & \\
\hline Denmark & 36 & 32 & 32 & 100 \\
Finland & 18 & 30 & 24 & 72 \\
Iceland & 4 & 3 & 6 & 13 \\
Norway & 20 & 14 & 24 & 58 \\
Sweden & 80 & 70 & 71 & 221 \\
TOTAL & 158 & 149 & 157 & 464 \\
\hline Panel B: Response rates $(\boldsymbol{\%})$ & & & & \\
\hline Denmark & $19.1 \%$ & $17.0 \%$ & $25.0 \%$ & $19.8 \%$ \\
Finland & $13.8 \%$ & $23.1 \%$ & $18.8 \%$ & $18.6 \%$ \\
Iceland & $18.2 \%$ & $13.6 \%$ & $33.3 \%$ & $21.0 \%$ \\
Norway & $10.6 \%$ & $7.4 \%$ & $12.9 \%$ & $10.3 \%$ \\
Sweden & $31.7 \%$ & $27.8 \%$ & $28.3 \%$ & $29.3 \%$ \\
ALL & $20.3 \%$ & $19.1 \%$ & $22.1 \%$ & $20.4 \%$ \\
\hline \hline
\end{tabular}




\section{TABLE 2. Descriptive statistics for responding firms and the target population}

Descriptive statistics are reported for the listed firms in Denmark, Finland, Iceland, Norway and Sweden that were targeted in the survey (the "Population", 780 firms). We also report statistics for the responding firms (the "Sample", 352 firms) from which firms we received a filled-in questionnaire from at least one respondent. The firms are divided into Financials (banks, investment and insurance companies) and Nonfinancials based on the sector codes used by the OMX exchanges and Oslo Børs (both use the same ten categories). We report averages, medians, standard deviations, and the number of firms for which the financial information item has been obtained ("Obs") for the following variables: Turnover (in 1000s of euros), No. of employees, Total assets (in 1000s of euros), Return on total assets (ROA, defined as Net Profit to Total Assets) and Solidity (defined as Equity to Total Assets). The financial data applies to the last available reporting year prior to the date that the questionnaire was sent out (typically 2007 for Norway and 2006 for the others). The data was collected from Amadeus, Datastream, and annual reports for the companies.

\begin{tabular}{|c|c|c|c|c|c|}
\hline & & \multicolumn{2}{|c|}{ Non-financials } & \multicolumn{2}{|c|}{ Financials } \\
\hline & & Sample & Population & Sample & Population \\
\hline \multicolumn{2}{|l|}{ Firms } & 285 & 615 & 67 & 165 \\
\hline \multirow{4}{*}{$\begin{array}{l}\text { Turnover, } \\
1000 \text { EUR }\end{array}$} & Mean & 1280296 & 1058814 & 736835 & 543775 \\
\hline & Median & 106970 & 101826 & 94865 & 53981 \\
\hline & St. dev. & 4675704 & 3939259 & 1946139 & 2039941 \\
\hline & Obs & 280 & 604 & 57 & 142 \\
\hline \multirow{4}{*}{$\begin{array}{l}\text { Number of } \\
\text { employees }\end{array}$} & Mean & 4539 & 4405 & 1494 & 1520 \\
\hline & Median & 482 & 396 & 190 & 135 \\
\hline & St. dev. & 16653 & 22460 & 4403 & 4679 \\
\hline & Obs & 272 & 569 & 59 & 139 \\
\hline \multirow{4}{*}{$\begin{array}{l}\text { Total assets, } \\
1000 \text { EUR }\end{array}$} & Mean & 1285241 & 1049915 & 12054523 & 12379270 \\
\hline & Median & 107249 & 102364 & 690387 & 570934 \\
\hline & St. dev. & 4562082 & 3696905 & 48051720 & 53042764 \\
\hline & Obs & 285 & 615 & 67 & 165 \\
\hline \multirow{4}{*}{$\begin{array}{l}\text { ROA, } \\
\text { percent }\end{array}$} & Mean & 4.13 & 4.22 & 6.86 & 5.95 \\
\hline & Median & 7.34 & 6.40 & 3.88 & 2.40 \\
\hline & St. dev. & 17.61 & 16.28 & 9.18 & 9.64 \\
\hline & Obs & 283 & 613 & 67 & 162 \\
\hline \multirow{4}{*}{$\begin{array}{l}\text { Solidity, } \\
\text { percent }\end{array}$} & Mean & 47.72 & 49.07 & & \\
\hline & Median & 45.43 & 45.58 & & \\
\hline & St. dev. & 19.35 & 20.11 & & \\
\hline & Obs & 282 & 610 & & \\
\hline
\end{tabular}




\section{TABLE 3. Target range for debt ratio}

Chairmen were first asked whether the company has a target range for the debt ratio. Four alternatives were given (no target, flexible target, somewhat flexible target, strict target). Then they were asked to indicate the degree to which the given factors contribute to the debt target. CFOs were also asked the same question. Answers were given on a scale from 1 (not important) to 5 (very important). Panel A reports the results about the existence of the policy. Panels B and C report the respondents' opinions on the given set of factors influencing the debt level. Results are given first for the Chairmen, then for the CEOs. $N$ and $N_{\text {empty }}$ are the total number of respondents with non-empty or empty reply, respectively.

\begin{tabular}{|c|c|c|c|c|c|c|}
\hline & & $\mathbf{N}$ & No target & Flexible & Medium & Strict \\
\hline \multicolumn{7}{|c|}{$\begin{array}{l}\text { Panel A: Target range for } \\
\text { debt ratio }\end{array}$} \\
\hline \multirow[t]{2}{*}{ All } & $\mathrm{N}$ (empty) & $145(13)$ & 28 & 39 & 49 & 29 \\
\hline & $\%$ of all & & $19.3 \%$ & $26.9 \%$ & $33.8 \%$ & $20.0 \%$ \\
\hline \multicolumn{2}{|c|}{ Denmark } & 32 & $28.1 \%$ & $25.0 \%$ & $28.1 \%$ & $18.8 \%$ \\
\hline \multicolumn{2}{|c|}{ Finland } & 18 & $5.6 \%$ & $27.8 \%$ & $38.9 \%$ & $27.8 \%$ \\
\hline \multicolumn{2}{|c|}{ Iceland } & 4 & $0.0 \%$ & $0.0 \%$ & $75.0 \%$ & $25.0 \%$ \\
\hline \multicolumn{2}{|c|}{ Norway } & 18 & $16.7 \%$ & $44.4 \%$ & $22.2 \%$ & $16.7 \%$ \\
\hline \multicolumn{2}{|c|}{ Sweden } & 73 & $20.5 \%$ & $24.7 \%$ & $35.6 \%$ & $19.2 \%$ \\
\hline \multicolumn{2}{|c|}{ Panel B: Factors, CM } & $\mathbf{N}$ & Mean & Median & Std. dev. & $\mathbf{N}_{\text {Empty }}$ \\
\hline \multicolumn{2}{|c|}{ Financial flexibility } & 150 & 4.39 & 4 & 0.55 & 8 \\
\hline \multicolumn{2}{|c|}{ Financing operations } & 144 & 4.08 & 4 & 0.99 & 14 \\
\hline \multicolumn{2}{|c|}{$\begin{array}{l}\text { Volatility of earnings/cash } \\
\text { flows }\end{array}$} & 139 & 3.49 & 4 & 1.09 & 19 \\
\hline \multicolumn{2}{|c|}{ Credit rating } & 139 & 3.27 & 4 & 1.24 & 19 \\
\hline \multicolumn{2}{|c|}{ Costs and fees of issuing debt } & 133 & 2.75 & 3 & 1.10 & 25 \\
\hline \multicolumn{2}{|c|}{ Tax advantage (interest) } & 139 & 2.72 & 3 & 1.12 & 19 \\
\hline \multicolumn{2}{|c|}{ Costs of distress/bankruptcy } & 130 & 2.67 & 2 & 1.43 & 28 \\
\hline \multicolumn{2}{|c|}{ Debt level of competitors } & 137 & 2.30 & 2 & 1.06 & 21 \\
\hline \multicolumn{2}{|c|}{ Personal tax on interest } & 131 & 2.18 & 2 & 1.04 & 27 \\
\hline \multicolumn{2}{|c|}{$\begin{array}{l}\text { Debt high enough to avoid } \\
\text { being a takeover target }\end{array}$} & 134 & 2.01 & 2 & 1.05 & 24 \\
\hline \multicolumn{2}{|c|}{ Panel C: Factors, CFO } & $\mathbf{N}$ & Mean & Median & Std. dev. & $\mathbf{N}_{\text {Empty }}$ \\
\hline \multicolumn{2}{|c|}{ Financial flexibility } & 141 & 4.22 & 4 & 0.71 & 16 \\
\hline \multicolumn{2}{|c|}{ Financing operations } & 143 & 3.87 & 4 & 1.04 & 14 \\
\hline \multicolumn{7}{|c|}{ Volatility of earnings/cash } \\
\hline \multicolumn{2}{|c|}{ Stock valuation } & 135 & 2.84 & 3 & 1.13 & 22 \\
\hline \multicolumn{2}{|c|}{ Costs and fees of issuing debt } & 132 & 2.70 & 3 & 1.10 & 25 \\
\hline \multicolumn{2}{|c|}{ Credit rating } & 129 & 2.61 & 3 & 1.29 & 28 \\
\hline \multicolumn{2}{|c|}{ Tax advantage (interest) } & 132 & 2.47 & 2 & 1.12 & 25 \\
\hline \multicolumn{2}{|c|}{ Costs of distress/bankruptcy } & 132 & 2.33 & 2 & 1.22 & 25 \\
\hline \multicolumn{2}{|c|}{ Debt level of competitors } & 133 & 2.26 & 2 & 1.02 & 24 \\
\hline \multicolumn{2}{|c|}{$\begin{array}{l}\text { Debt high enough to avoid } \\
\text { being a takeover target }\end{array}$} & 130 & 1.77 & 2 & 0.89 & 27 \\
\hline
\end{tabular}




\section{TABLE 4. Debt ratio target range strictness}

Results from an ordered probit model are reported, where the ordinary dependent variable Strict_cap_struct can have values from zero to three (zero= no target value for debt/equity ratio, one $=$ flexible target, two $=$ somewhat tight target range, and three $=$ strict target range). The explanatory variables are: net profit over total assets $(R O A)$, the natural logarithm of turnover (In(turnover)), equity to total assets (Solidity), market value of equity over book value of equity (Market-to-book), the percentage change in annual sales between last two years (Past_12m_sales_growth), the logarithm of firm age (In_firm_age), the logarithm of the age of the chairman of the board ( $I n \_C M_{-}$age), a dummy for firms paying dividends around the survey (Div_pay), and a dummy for firms indicating in the survey that they have a definite dividend policy (Div_policy_dummy). Country dummies for Denmark, Norway and Sweden as well as for manufacturing and financial firms are included. Robust standard errors are used to calculate $\mathrm{z}$-values (provided below the parameter estimates). *, **, and $* * *$ denote significance at the $10 \%, 5 \%$, and $1 \%$ levels, one-sided tests. The Wald $\chi^{2}$ and the Pseudo- $\mathrm{R}^{2}$ are also reported.

\begin{tabular}{|c|c|c|c|c|}
\hline Explanatory variables & Model I & Model II & Model III & Model IV \\
\hline ROA & $\begin{array}{c}0.0312 \\
(3.46) * * *\end{array}$ & $\begin{array}{c}0.0294 \\
(2.89)^{* * * *}\end{array}$ & $\begin{array}{c}0.0228 \\
(2.07)^{* * *}\end{array}$ & $\begin{array}{c}0.0252 \\
(2.34)^{* *}\end{array}$ \\
\hline $\ln$ (turnover) & $\begin{array}{l}-0.0695 \\
(-1.30)\end{array}$ & $\begin{array}{l}-0.0596 \\
(-1.04)\end{array}$ & $\begin{array}{l}-0.0766 \\
(-1.39)\end{array}$ & $\begin{array}{c}-0.1082 \\
(-1.89)^{*}\end{array}$ \\
\hline Solidity & $\begin{array}{c}-0.0169 \\
(-3.02)^{* * * *}\end{array}$ & $\begin{array}{c}-0.0165 \\
(-2.89)^{* * *}\end{array}$ & $\begin{array}{c}-0.0158 \\
(-2.76)^{* * *}\end{array}$ & $\begin{array}{c}-0.0162 \\
(-2.79)^{* * *}\end{array}$ \\
\hline Market-to-book & & $\begin{array}{l}0.0175 \\
(0.94)\end{array}$ & $\begin{array}{l}0.0179 \\
(0.92)\end{array}$ & $\begin{array}{l}0.0143 \\
(0.67)\end{array}$ \\
\hline Past_12m_sales_growth & & $\begin{array}{l}0.0579 \\
(0.69)\end{array}$ & $\begin{array}{l}-0.0678 \\
(-0.80)\end{array}$ & $\begin{array}{l}0.1365 \\
(1.51)\end{array}$ \\
\hline ln_firm_age & $\begin{array}{c}0.2763 \\
(2.39)^{* *}\end{array}$ & $\begin{array}{c}0.2583 \\
(2.10)^{* *}\end{array}$ & $\begin{array}{c}0.2613 \\
(2.10)^{* * *}\end{array}$ & $\begin{array}{c}0.2490 \\
(1.89)^{*}\end{array}$ \\
\hline ln_CM_age & $\begin{array}{c}1.3718 \\
(1.98)^{* * *}\end{array}$ & $\begin{array}{c}1.4735 \\
(1.97)^{* *}\end{array}$ & $\begin{array}{l}1.4579 \\
(1.92)^{*}\end{array}$ & $\begin{array}{l}1.8642 \\
(2.26)^{* *}\end{array}$ \\
\hline Div_pay & & & $\begin{array}{r}-0.4779 \\
(-1.94)^{*}\end{array}$ & \\
\hline Div_policy_dummy & & & & $\begin{array}{l}1.0817 \\
(3.91)^{* * *}\end{array}$ \\
\hline Obs $(\mathrm{N})$ & 133 & 127 & 127 & 124 \\
\hline Sector dummies & Yes & Yes & Yes & Yes \\
\hline Country dummies & Yes & Yes & Yes & Yes \\
\hline Wald Chi2 & 45.44 & 49.59 & 50.53 & 59.99 \\
\hline Pseudo $\mathrm{R}^{2}(\%)$ & 10.75 & 12.19 & 13.07 & 16.62 \\
\hline
\end{tabular}




\section{TABLE 5. Short vs. long term debt}

CFOs were asked what factors affect their company's choice between short and long-term debt. Five alternatives were listed and they were asked to indicate whether the given factor's importance. Answers were given on a scale from 1 (not important) to 5 (very important). $N$ and $N_{\text {empty }}$ are the total number of respondents with non-empty or empty reply, respectively.

\begin{tabular}{lccccc}
\hline & $\mathbf{N}$ & Mean & Median & Std. dev. & $\mathbf{N}_{\text {Empty }}$ \\
\hline $\begin{array}{l}\text { Use long-term to minimize } \\
\text { risk of financial distress }\end{array}$ & 142 & 3.47 & 4 & 1.13 & 15 \\
$\begin{array}{l}\text { Match maturity of debt and } \\
\text { assets }\end{array}$ & 136 & 3.21 & 3 & 1.18 & 21 \\
$\begin{array}{l}\text { Use short-term to wait long- } \\
\text { term rates to decline }\end{array}$ & 134 & 2.37 & 2 & 0.98 & 23 \\
$\begin{array}{l}\text { Long-term debt increases risk } \\
\text { of taking on more risk project }\end{array}$ & 129 & 2.09 & 2 & 0.88 & 28 \\
$\begin{array}{l}\text { Expect rating to improve, so } \\
\text { short-term issued until } \\
\text { happened }\end{array}$ & 130 & 1.80 & 2 & 0.94 & 27 \\
\hline \hline
\end{tabular}




\section{TABLE 6. Seasoned equity offering}

CFOs were first asked whether the company has seriously considered issuing common stock. If yes, they were asked to indicate the degree the importance of the given factors in their choice of issuing stock. Answers were given on a scale from 1 (not important) to 5 (very important). Panel A reports the results for the first question. Panel B reports the results for the factors influencing the offering decision. $N$ and $N_{\text {empty }}$ are the total number of respondents with non-empty or empty reply, respectively.

\begin{tabular}{|c|c|c|c|c|c|c|}
\hline & & $\mathbf{N}$ & Yes & No & & $\mathbf{N}_{\text {Empty }}$ \\
\hline \multicolumn{7}{|c|}{ Panel A: Considered issuing } \\
\hline \multirow[t]{2}{*}{ All } & $\mathrm{N}$ & 152 & 54 & 98 & & 5 \\
\hline & $\%$ of all & & $35.5 \%$ & $64.5 \%$ & & \\
\hline \multicolumn{2}{|c|}{ Panel B: Factors } & $\mathbf{N}$ & Mean & Median & Std. dev. & $\mathbf{N}_{\text {Empty }}$ \\
\hline \multicolumn{2}{|c|}{ Earnings per share dilution } & 62 & 3.44 & 4 & 1.21 & 95 \\
\hline \multicolumn{2}{|c|}{$\begin{array}{l}\text { Our recent profits have not } \\
\text { been sufficient to fund } \\
\text { activities }\end{array}$} & 58 & 3.19 & 4 & 1.32 & 99 \\
\hline \multicolumn{2}{|c|}{$\begin{array}{l}\text { Inability to obtain funds from } \\
\text { other sources }\end{array}$} & 60 & 3.05 & 3 & 1.36 & 97 \\
\hline \multicolumn{2}{|c|}{ Utilize high valuation } & 57 & 2.93 & 3 & 1.08 & 100 \\
\hline \multicolumn{2}{|c|}{ Maintain debt-to-equity ratio } & 60 & 2.93 & 3 & 1.23 & 97 \\
\hline \multicolumn{2}{|c|}{ Stock under/overvalued } & 58 & 2.62 & 3 & 1.23 & 99 \\
\hline \multicolumn{2}{|c|}{ Employee stock option plan } & 60 & 2.58 & 2 & 1.29 & 97 \\
\hline \multicolumn{2}{|c|}{$\begin{array}{l}\text { Dilute holdings of certain } \\
\text { owners }\end{array}$} & 58 & 2.52 & 2 & 1.33 & 99 \\
\hline \multicolumn{2}{|c|}{$\begin{array}{l}\text { Comparison to competitors } \\
\text { debt-to-equity ratios }\end{array}$} & 57 & 2.21 & 2 & 1.11 & 100 \\
\hline \multicolumn{2}{|c|}{$\begin{array}{l}\text { Taxation (capital gains tax vs. } \\
\text { tax on dividends) }\end{array}$} & 56 & 1.82 & 2 & 0.90 & 101 \\
\hline
\end{tabular}




\section{TABLE 7. Convertible debt}

CFOs were first asked whether the company has seriously considered issuing convertible debt or issued in the last two years. If yes, they were asked to indicate the degree the importance of the given factors in their choice of issuing convertible debt. Answers were given on a 1 (not important) to 5 (very important) scale. Panel A reports the results for the first question. Panel B reports the results for the factors influencing the offering decision. $N$ and $N_{\text {empty }}$ are the total number of respondents with non-empty or empty reply, respectively.

\begin{tabular}{|c|c|c|c|c|c|c|}
\hline & & $\mathbf{N}$ & Yes & \multicolumn{2}{|l|}{ No } & $\mathbf{N}_{\text {Empty }}$ \\
\hline \multicolumn{7}{|c|}{ Panel A: Considered issuing } \\
\hline \multirow[t]{2}{*}{ All } & $\mathrm{N}$ & 154 & 32 & 122 & & 0 \\
\hline & $\%$ of all & & $20.8 \%$ & $79.2 \%$ & & \\
\hline \multicolumn{2}{|c|}{ Panel B: Factors } & $\mathbf{N}$ & Mean & Median & Std. dev. & $\mathbf{N}_{\text {Empty }}$ \\
\hline \multicolumn{2}{|c|}{ Less expensive than debt } & 29 & 3.14 & 3 & 1.33 & 3 \\
\hline \multicolumn{2}{|c|}{$\begin{array}{l}\text { Avoid short-term equity } \\
\text { dilution }\end{array}$} & 31 & 3.03 & 3 & 1.40 & 1 \\
\hline \multicolumn{2}{|c|}{ Stock is undervalued } & 31 & 2.90 & 3 & 1.42 & 1 \\
\hline \multicolumn{2}{|c|}{$\begin{array}{l}\text { Ability to force conversion } \\
\text { when need to }\end{array}$} & 31 & 2.84 & 3 & 1.19 & 1 \\
\hline \multicolumn{2}{|c|}{ Attract investors } & 30 & 2.67 & 3 & 1.18 & 2 \\
\hline \multicolumn{2}{|c|}{ Others have used successfully } & 30 & 2.53 & 3 & 1.20 & 2 \\
\hline \multicolumn{2}{|c|}{$\begin{array}{l}\text { Protect bondholders against } \\
\text { managers/stockholders }\end{array}$} & 31 & 2.23 & 2 & 1.15 & 1 \\
\hline
\end{tabular}

